dalske. København.

Berger, A. 1925. Roseocactus, a new genus of Cactaceae. Jour. Wash. (D.C.) Acad. Sci. 15: 43-48.

BoKe, N. H. 1959. Endomorphic and ectomorphic characters in Pelecyphora and Encephalocarpus. Amer. Jour. Bot. 46: 197-209.

Bravo H., Helia. 1937. Las Cactáceas de México. Universidad Nacional de México. Mexico City.

Britton, N. L., and J. N. Rose. 1923. The Cactaceae. Carnegie Inst. Washington Publ. No. 248.

Buxbaum, F. 1950. Morphology of Cacti. Abbey Garden Press. Pasadena. Section 1.

_- 1953. Morphology of Cacti. Abbey Garden Press. Pasadena. Sections 2 and 3.

Darlington, C. D., and A. P. Wylie. 1955. Chromosome atlas of flowering plants. George Allen and Unwin Ltd, London.

Engelmann, G. 1859. Cactaceae of the boundary. United States and Mexican Boundary Survey under Lt. Col. W. H. Emory. U.S. Government Printing Office. Washington, D.C.

Erdtman, G. 1943. An introduction to pollen analysis. Chronica Botanica Co. Waltham.
1952. Pollen morphology and plant taxonomyangiosperms. Chronica Botanica Co. Waltham.

Ewell, E. E. 1896. The chemistry of the Cactaceae. Jour. Amer. Chem. Soc. 18: 624-643.

Johansen, D. A. 1933. Recent work on the cytology of the cacti. Cact. Succ. Jour. 4: 356.

Katagiri, S. 1953. Chromosome numbers and polyploidy in certain Cactaceae. Cact. Succ. Jour. 25: 141-143.

Kurtz, E. B., JR. 1948. Pollen grain characters of certain Cactaceae. Bull. Torrey Bot. Club 75: 516-522.

Marshall, W. T., and T. M. Bock. 1941. Cactaceae. Ab. bey Garden Press. Pasadena.

RETI, L. 1950. Cactus alkaloids and some related compounds. Progress in the chemistry of organic natural products. Springer. Wien.

Schultes, R. E. 1937a. Peyote and plants used in the peyote ceremony. Bot. Mus. Leafl., Harvard Univ. 4: $129-152$.

- 1937b. Peyote (Lophophora williamsii) and plants confused with it. Bot. Mus. Leafl., Harvard Univ. 5: 61-68.

Wodehouse, R. P. 1935. Pollen grains. McGraw-Hill Co. New York.

\title{
REVERSIBLE DEACTIVATION OF NEUROSPORA ASCOSPORES BY LOW TEMPERATURE ${ }^{1}$ \\ Clare Y. Sun and Alfred S. Sussman
}

\begin{abstract}
A B S T R A C T
Sun, Clare Y., and Alfred S. Sussman. (U. Michigan, Ann Arbor.) Reversible deactivation of Neurospora ascospores by low temperature. Amer. Jour. Bot. 47(7) : 589-593. Illus. 1960.Heat-activated ascospores of Neurospora tetrasperma are reversibly deactivated after incubation at $4^{\circ} \mathrm{C}$. for $36-48 \mathrm{hr}$. Two cycles of deactivation and reactivation are possible although the percentage germination decreases in the last cycle. By contrast, spores held at $20^{\circ} \mathrm{C}$., or in glycerol at $4^{\circ} \mathrm{C}$., will remain activated for much longer periods of time. If an incubation period at $20^{\circ} \mathrm{C}$. greater than $30 \mathrm{~min}$. is interposed before the activated spores are placed at $4^{\circ} \mathrm{C}$., germination occurs despite the cold-treatment. Furfural-activated ascospores, when held at $4^{\circ} \mathrm{C}$., are deactivated but can be reactivated only by heat, pointing up a difference between ascospores activated by these different means. Although a fraction of the stimulus afforded by heat-sensitization to chemical activators is preserved for 2 days at $-20^{\circ} \mathrm{C}$., it is dissipated completely after a short time at $4^{\circ} \mathrm{C}$. These data are discussed on the basis of the suggestion that the reversible production of a substance initiates a series of steps which lead to germination. Thus, the temperature minimum of the forward reaction is greater than $4^{\circ} \mathrm{C}$. whereas the back reaction proceeds at this temperature.
\end{abstract}

IN THE model proposed by Goddard (1939) to explain the activation of Neurospora ascospores by heat, it was assumed that a substance, $\mathrm{S}$, is converted to a product, $P$, according to the following reaction:

$$
\mathrm{S} \rightleftharpoons \mathrm{P}
$$

The increase in respiration attendant upon activation depends directly upon the concentration of $P$, but its maintenance, after induction, does not require the continued presence of $P$. Thus, heat activation at $50-60^{\circ} \mathrm{C}$. is required to shift the equilibrium of the above reaction to the right, whereas at lower temperatures it is in the other direction and $\mathrm{P}$ is converted back to $\mathrm{S}$. Evidence for the

1 Received for publication November 17, 1959.

This work was supported in part by Research Grant \#G-5901 from the National Science Foundation. reversibility of the activation process was provided by Goddard (1939) and by Goddard and Smith (1938) who showed that activated spores were deactivated by incubation under anaerobic conditions or in certain respiratory poisons.

If the above reaction is accepted as a working hypothesis, then certain experimental procedures are indicated. Among these, the isolation of substance $P$, broadly defined to include metabolites, enzymes or coenzymes may be possible. Although such a substance has not yet been isolated, recent work suggests that its function may be connected with trehalose metabolism (Lingappa, B. T. and Sussman, 1959; Sussman and Lingappa, 1959). Another approach suggested by the hypothesis is based upon the possibility that the temperature minima of the forward and back reactions differ, 
as well as the temperature coefficients. Accordingly, incubation at a suitable temperature might resulit in the conversion of product $P$ to $S$ if the minimum temperature of the forward reaction is higher than that of the back reaction. In this event reversible deactivation is to be expected and the following experiments were designed to test this possibility.

Materials and Methods.-Ascospores of Neurospora tetrasperma were harvested, stored and prepared for use by the methods described previously (Sussman, 1954a). In all experiments, unless otherwise noted, ascospores that had been stored for about a year were used. The concentration of spores usually used gave a reading of 90 in the Klett colorimeter with a blue filter (Klett \# 42) and was equivalent to $0.5 \mathrm{mg}$. (dry weight) per $\mathrm{ml}$.

The breaking of dormancy usually was accomplished by placing ascospores suspended in water in a constant temperature bath at $60^{\circ} \mathrm{C}$. for $10 \mathrm{~min}$. In certain experiments the spores were activated by suspension in furfural at a final concentration of $1 \times 10^{-3} \mathrm{M}$. When chemical activation was performed the spores were first exposed to $45^{\circ} \mathrm{C}$. in a water bath for $40 \mathrm{~min}$. in order to induce the re. covery of sensitivity to furfural (Sussman, 1954b).

Incubation of the activated ascospores was usu. ally performed at $27^{\circ} \mathrm{C}$. for $3-4 \mathrm{hr}$. on a shaking machine with a reciprocal movement. For treatment at low temperatures, the spores were stored in the main compartment of a refrigerator $\left(4^{\circ} \mathrm{C}\right.$. $)$ or in the freezer compartment which was main. tained at $-15^{\circ} \mathrm{C}$. to $-20^{\circ} \mathrm{C}$.

Germination counts were made on duplicate sam. ples and at least 2 separate counts of 600 spores were averaged for each determination.

REsults.-Effect of storage at low temperature upon heat-activated ascospores.--Previous work has disclosed that the minimum temperature for the germination of ascospores of Neurospora is about $6^{\circ} \mathrm{C}$. (Lingappa, Y., and Sussman, 1959). Consequently, attempts were made to interfere with the activation mechanism by exposure of the spores to temperatures below this minimum. Ascospores were heat-activated for $10 \mathrm{~min}$. and duplicate $2-\mathrm{ml}$. aliquots were removed and incubated at $27^{\circ} \mathrm{C}$. The remainder of the spores was placed at $4^{\circ} \mathrm{C}$. At periodic intervals, thereafter, duplicate samples were removed, incubated at $27^{\circ} \mathrm{C}$. as before, and
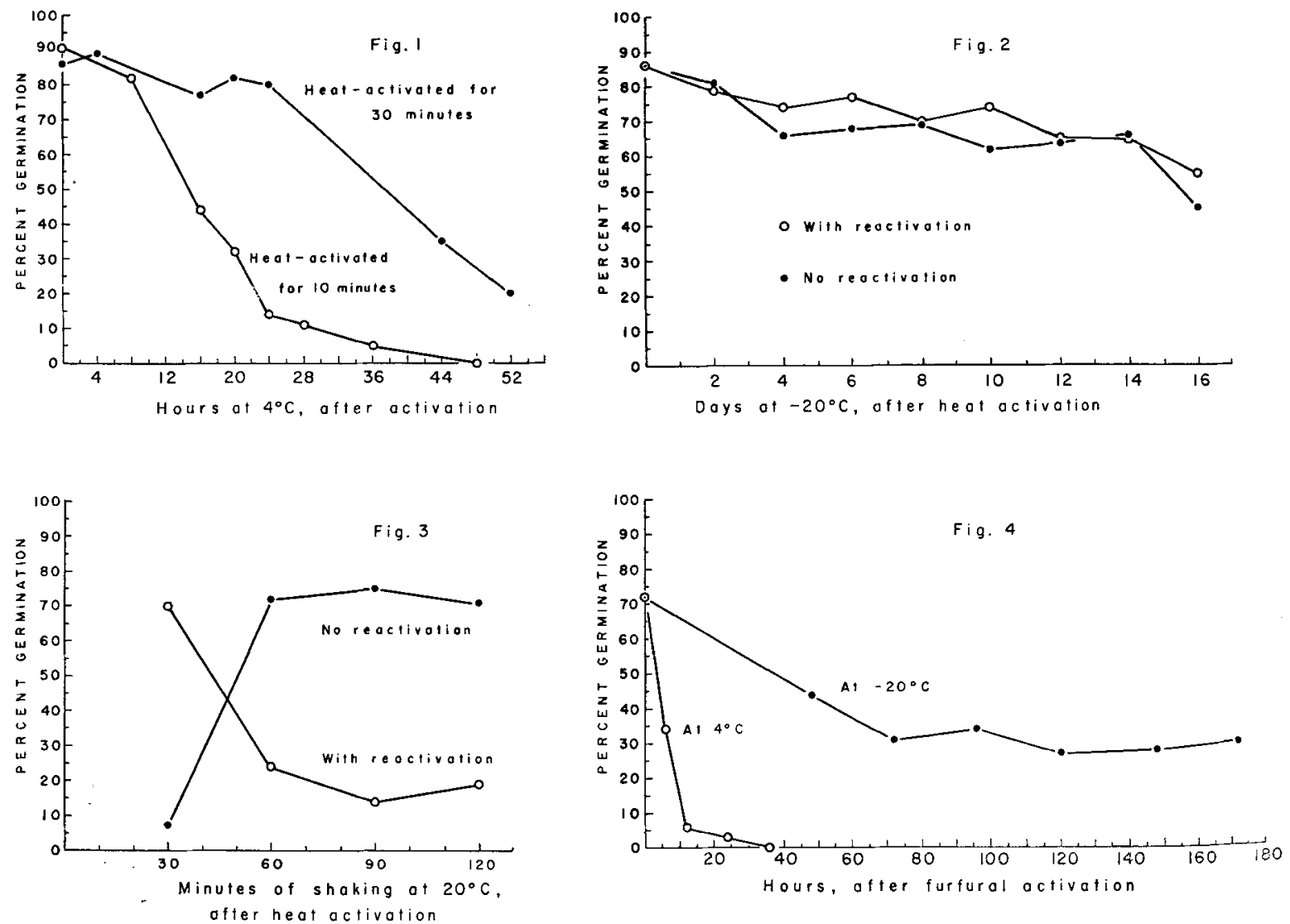

Fig. 1-4.-Fig. 1. Effect of storage at $4^{\circ} \mathrm{C}$. upon the germination of ascospores activated for different lengths of time at $60^{\circ} \mathrm{C}$. - Fig. 2. Germinability of heat-activated ascospores after storage for various times at $-20^{\circ} \mathrm{C}$. Reactivation was accomplished by exposure of spores to $60^{\circ} \mathrm{C}$. for $10 \mathrm{~min}$.-Fig. 3. Effect of storage at $4^{\circ} \mathrm{C}$. upon germination of heat-activated ascospores incubated at $20^{\circ} \mathrm{C}$. for various lengths of time after activation. Reactivation was accomplished as above. -Fig. 4. Germinability of ascospores activated by $1 \times 10^{-3} \mathrm{M}$ furfural after storage at $4^{\circ}$ and $-20^{\circ} \mathrm{C}$. 
the percentage germination after $4 \mathrm{hr}$. determined. The results in fig. 1 disclose that only $14 \%$ of the spores remain activated after storage at $4{ }^{\circ} \mathrm{C}$. for $24 \mathrm{hr}$. and that none germinate after $48 \mathrm{hr}$.

That the length of the heat-activation treatment influences the rate at which the percentage germination decreases during storage at $4^{\circ} \mathrm{C}$. also may be seen in fig. 1 . Thus, despite the fact that there is very little difference in the number of spores which germinate after activation periods of 10 and 30 min., the "decay" of germinability at $4{ }^{\circ} \mathrm{C}$. is much slower in the latter case. In fact, after $52 \mathrm{hr} .20 \%$ of the spores still germinated.

In order to determine whether activated spores stored at low temperatures lose their viability, or are simply deactivated, they were exposed to $60^{\circ} \mathrm{C}$. for $10 \mathrm{~min}$., after removal from $4^{\circ} \mathrm{C}$., and incubated at $27^{\circ} \mathrm{C}$. It is clear from the data in table 1 that the latter is the case and that storage at $4^{\circ} \mathrm{C}$. results in the gradual deactivation of ascospores.

The number of cycles of activation and deactivation of which the ascospores are capable was studied by storing activated cells for $144 \mathrm{hr}$. at $4{ }^{\circ} \mathrm{C}$. At 48-hr. intervals during this time, samples were withdrawn, reactivated, incubated at $27^{\circ} \mathrm{C}$. and the percentage of germination determined. Parallel sam. ples were incubated at $27^{\circ} \mathrm{C}$. without being heatactivated again and served as a check upon the level of germination after cold-storage. As the data in table 2 reveal, the limit is only 2 cycles under the conditions of these experiments and, even after the second cycle, there is about a $30 \%$ decrease in germinability.

Some of the experiments at $4{ }^{\circ} \mathrm{C}$. reported above were repeated at $-20^{\circ} \mathrm{C}$. Thus, activated ascospores were stored at this temperature for various periods

TABLE 1. Effect of reactivation upon ascospores incubated at $4^{\circ} \mathrm{C}$. after their first activation treatment. Spores were removed from $4^{\circ} \mathrm{C}$., reactivated by suspension in water at $60^{\circ} \mathrm{C}$. for $10 \mathrm{~min}$, and then incubated at $27^{\circ} \mathrm{C}$.

\begin{tabular}{ccc}
\hline & \multicolumn{2}{c}{ Percentage germination } \\
$\begin{array}{c}\text { Time of storage } \\
\text { at } 4^{\circ} \mathrm{C} .(\mathrm{hr} .)\end{array}$ & $\begin{array}{c}\text { control } \\
\text { spores }\end{array}$ & $\begin{array}{c}\text { reactivated } \\
\text { spores }\end{array}$ \\
\hline 36 & 5 & 85 \\
60 & 0 & 60 \\
\hline
\end{tabular}

TABLE 2. Cycles of activation and deactivation of ascospores of $N$. tetrasperma due to treatment at $4^{\circ} \mathrm{C}$. Ascospores were activated and stored at $4^{\circ} \mathrm{C}$. for $48-\mathrm{hr}$. periods after which they were reactivated and aliquots were incubated at $27^{\circ} \mathrm{C}$. or returned to $4^{\circ} \mathrm{C}$.

\begin{tabular}{cccc} 
& & \multicolumn{2}{c}{ Percentage germination } \\
\cline { 3 - 4 } $\begin{array}{c}\text { Hrs, after first } \\
\text { activation }\end{array}$ & $\begin{array}{c}\text { Number of } \\
\text { cycles }\end{array}$ & $\begin{array}{c}\text { not } \\
\text { reactivated }\end{array}$ & reactivated \\
\hline 0 & Control & 86 & - \\
48 & 1 & 0 & 87 \\
96 & 2 & 0 & 63 \\
144 & 3 & 0 & 0 \\
\hline
\end{tabular}

of time after which they were incubated at $27^{\circ} \mathrm{C}$. and the percentage germination determined. Figure 2 shows that even after 16 days $(384 \mathrm{hr}$.) at this low temperature, if the spores are placed at $27^{\circ} \mathrm{C}$., about $50 \%$ will germinate with no additional heat treatment. Furthermore, these data also reveal that another heat activation has only a small effect upon activated spores stored at $-20^{\circ} \mathrm{C}$.

That there are at least 2 phases in the develop. ment of activated ascospores, recognizable through differences in their physiological characteristics, has been suggested by Sussman et al. (1956) and Lingappa, Y., and Sussman (1959). Therefore, a period of shaking at $20^{\circ} \mathrm{C}$. was interposed between the treatment at $4^{\circ} \mathrm{C}$. and the final incubation at $27^{\circ} \mathrm{C}$. during which germination occurs. In these experiments, the spores were maintained at $4^{\circ} \mathrm{C}$. for $48 \mathrm{hr}$. and the length of the first exposure to $20^{\circ} \mathrm{C}$. varied as indicated in fig. 3 . Ascospores incubated at $20^{\circ} \mathrm{C}$. for up to $30 \mathrm{~min}$. before transfer to $4{ }^{\circ} \mathrm{C}$. were reversibly deactivated in accordance with the results obtained previously. On the other hand, when such spores are incubated for longer than 30 min. at $20^{\circ} \mathrm{C}$., they maintain their state of activation even after storage at $4{ }^{\circ} \mathrm{C}$. for $48 \mathrm{hr}$. The provision of another heat-treatment to such spores results in a considerable decrease in their germinability.

Thus far, all the evidence supports the notion that a reversible chemical reaction, like that discussed in the introduction, occurs as a result of activation. In order to subject this model to a further test, ascospores were immersed in $100 \%$ glycerol, a treatment which results in the loss of most of the cell's water. Observation of the spores after such treatment reveals that almost all of the spores have collapsed such that they are crescent-shaped when observed laterally. This means of drying the cells was used because it had been observed that complete viability is retained during this treatment (Lowry and Sussman, unpublished observations). Accordingly, activated ascospores were immersed in $100 \%$ glycerol and stored at $4^{\circ} \mathrm{C}$. for various

TABLE 3. Effect of dehydration in glycerol upon the deactivation of ascospores of $N$. tetrasperma at $4^{\circ} \mathrm{C}$. Activation was accomplished at $60^{\circ} \mathrm{C}$. for $10 \mathrm{~min}$. and the spores were immediately immersed in glycerol and stored at $4^{\circ} \mathrm{C}$.

\begin{tabular}{cc}
\hline $\begin{array}{c}\text { Hr. storage } \\
\text { at } 4^{\circ} \mathrm{C} .\end{array}$ & $\begin{array}{c}\text { Percentage } \\
\text { germination }\end{array}$ \\
\hline 0 & 82 \\
12 & 76 \\
24 & 74 \\
36 & 75 \\
48 & 70 \\
60 & 69 \\
72 & 57 \\
84 & 54 \\
96 & 60 \\
120 & 55
\end{tabular}


lengths of time. Thereafter, the glycerol was removed by centrifugation in 3 changes of water and the spores were incubated in water at $27^{\circ} \mathrm{C}$. and the percentage of germination determined. In direct contrast to activated ascospores that have been stored at $4^{\circ} \mathrm{C}$. in water (fig. 1), those dried in glycerol before such treatment are deactivated to only a small extent after $48 \mathrm{hr}$. and fully $55 \%$ germinate even at the end of 5 days (table 3 ).

Effect of storage at low temperatures on furfuralactivated ascospores.-Emerson (1954) has drawn attention to certain differences between activation by chemical means and by heat. With this in mind, ascospores (1 $\mathrm{mg}$. per $\mathrm{ml}$.) were heat-sensitized at $45^{\circ} \mathrm{C}$. for $40 \mathrm{~min}$. and, after being cooled, were mixed with an equal volume of $2 \times 10^{-3} \mathrm{M}$ furfural. The spores were exposed to the furfural for $10 \mathrm{~min}$. and then were washed in several changes of dist. water by centrifugation. They were stored at $4^{\circ} \mathrm{C}$., or at $-20^{\circ} \mathrm{C}$., for varying lengths of time, iucubated at $27^{\circ} \mathrm{C}$ and the percentage germination determined. As can be seen in fig. 4, the general effects of cold temperatures upon heat-activated ascospores were observed for chemically activated ones as well. However, the decline in germinability is more precipitous in the case of furfural-activated spores for only $6 \%$ still germinate after only $12 \mathrm{hr}$. at $4{ }^{\circ} \mathrm{C}$. Also, in the case of spores held at $-20^{\circ} \mathrm{C}$. germinability decreases at a more rapid rate but fully $30 \%$ germinate after 7 days at this temperature.

Reactivation of furfural-activated ascospores, held at $4^{\circ} \mathrm{C}$. for 5 days, was attempted by the several means listed in table 4 but germination was elicited only by heating at $60^{\circ} \mathrm{C}$.

Ascospores maintain their peak in responsiveness to furfural during a very short time-interval shortly after they are released (Emerson, 1954). Consequently, except during that short time, heat-sensitization is a necessity before germination can be induced maximally by chemical means (Sussman, 1954b; Sussman et al., 1959). Thus, it was of interest to determine whether the enhanced responsiveness to chemical activation of heat-sensitized ascospores could be maintained by incubation at

TABLE 4. Reactivation of furfural-activated ascospores stored at $4^{\circ} \mathrm{C}$. for 5 days after activation. A final concentration of $1 \times 10^{-3} M$ furfural was used to activate throughout

\begin{tabular}{lc}
\hline Reactivation treatment & $\begin{array}{c}\text { Percentage } \\
\text { germination }\end{array}$ \\
\hline $\begin{array}{l}\text { Controls (activated in furfural before incu- } \\
\text { bation at } 4^{\circ} \mathrm{C} \text {.) }\end{array}$ & 72 \\
Incubated 5 days at $4^{\circ} \mathrm{C}$. and provided: & 0 \\
no further treatment & 84 \\
$60^{\circ} \mathrm{C}$. for 10 min. & 0 \\
$45^{\circ} \mathrm{C}$. for 40 min. & 0 \\
$45^{\circ} \mathrm{C}$. for 40 min. followed by re-exposure & 0 \\
to furfural & 0 \\
re-exposure to furfural & \\
\hline
\end{tabular}

low temperatures. Accordingly, ascospores (1 $\mathrm{mg}$. per ml.) were held at $45^{\circ} \mathrm{C}$. for $40 \mathrm{~min}$. and $\mathrm{im}$. mediately transferred to $4^{\circ}$ or $-20^{\circ} \mathrm{C}$. Aliquots were removed at intervals, brought to room temperature, exposed to $1 \times 10^{-3} \mathrm{M}$ furfural (final concentration) for $10 \mathrm{~min}$. and washed free of the chemical by centrifugation as described before. After incubation at $27^{\circ} \mathrm{C}$., germination was counted and the results outlined in table 5. Although some of the enhanced responsiveness induced by heatsensitization is retained for 2 days at $-20^{\circ} \mathrm{C}$., it is lost completely after only a day at $4^{\circ} \mathrm{C}$. Moreover, even at $-20^{\circ} \mathrm{C}$., the stimulus induced by heat-sensitization is dissipated after 3 days.

Discussion.- The reversible deactivation of as. cospores of $N$. tetrasperma during incubation at $4^{\circ} \mathrm{C}$. can be interpreted to mean that, at this temperature, the back reaction proceeds faster than the forward one. On the other hand, when activated spores are held at $-20^{\circ} \mathrm{C}$. (fig. 2), or at $4{ }^{\circ} \mathrm{C}$. dried in glycerol (table 3 ), neither reaction proceeds and deactivation does not occur.

As in the case of furfural-activated ascospores that have been deactivated by incubation under anaerobic conditions, those in which the reversal has been effected by low temperature are not reactivated by reincubation in furfural (Emerson, 1954; table 4). That the cells have not been killed by this treatment is clear from the fact that incubation at $60^{\circ} \mathrm{C}$. will reactivate such spores.

In the present experiments only 2 cycles of activation and deactivation were possible, that is, ascospores were activated 3 times and deactivated twice. However, the percentage germination after the last activation has decreased about $1 / 3$. These experiments are in agreement with those of Goddard (1939) who mentions in a footnote to his table 2 that one lot of spores germinated after the same number of cycles of activation and deactivation by anaerobic incubation. A difference that arises concerns the continued high percentage of germination, even after activation 3 times.

The work of Halbsguth and Rudolph (1959) on sporangiospores of Phycomyces blakesleeanus sug. gests that dormancy is reversible in fungi other than Neurospora. Thus incubation at $25^{\circ} \mathrm{C}$. in water, or under anaerobiosis, resulted in the deac-

TABLE 5. Effect of storage at low temperatures on enhanced responsiveness to chemical activators induced by heatsensitization at $45^{\circ} \mathrm{C}$. for $40 \mathrm{~min}$. Germinability was tested by exposing spores to $1 \times 10^{-3} M$ furfural for 10 min. followed by incubation at $27^{\circ} \mathrm{C}$.

\begin{tabular}{ccc}
\hline $\begin{array}{c}\text { Days of storage at } \\
\text { low temperature }\end{array}$ & \multicolumn{2}{c}{$\begin{array}{c}\text { Percentage germination } \\
\text { when stored at: }\end{array}$} \\
\hline 0 & $4{ }^{\circ} \mathrm{C}$. & $-20^{\circ} \mathrm{C}$. \\
\hline 1 & 50 & 50 \\
2 & 0 & 15 \\
3 & 0 & 17 \\
& - & 0 \\
\hline
\end{tabular}


tivation of heat-treated spores. Several cycles of activation and deactivation were possible although complete inactivation was not achieved in later cycles and, beginning with the fifth activation, such treatment reduced the percentage germination.

Further evidence for the step-wise transformation of the dormant ascospore to the vegetative (mycelial) condition is furnished by these data. Thus, fig. 3 reveals that reversion to the dormant state does not occur at $4{ }^{\circ} \mathrm{C}$. if incubation at $20^{\circ} \mathrm{C}$. for longer than $30 \mathrm{~min}$. is interposed between the activation treatment and exposure to low temperature. Antecedent to this change in the physiology of the activated spore is the loss of heat-resistance which is complete between $20-30 \mathrm{~min}$. after activation and can be detected within minutes after activation. That a fermentative type of metabolism ensues immediately upon activation has been shown by Sussman et al. (1956). This is followed by a different type of metabolism characterized by the use of lipids and the loss of fermentative capacity (Goddard, 1939; Lingappa, B. T., and Sussman, 1959). Many of these observations are summarized in table 6 which describes the physiological markers for the stages between activation and germination.

Three methods are now known for reversing the activation of ascospores of Neurospora including, incubation under anaerobic conditions, in poisons like cyanide (Goddard, 1939) and exposure to $4^{\circ} \mathrm{C}$. The representation of the events involved in the activation and reactivation processes presented by Goddard, and discussed in the introduction, does not imply that a unique mechanism can be formulated at this time. The fact that activation is reversible can be interpreted in several ways, which include: (1) Activation results in the production of a substance which triggers the changes which result in germination; the reaction is reversed by restriction of the synthesis of this material so that the steps which follow this initial one are not induced and the cell reverts to the dormant state.

TABLE 6. Summary of the stages between activation and germination and the physiological markers which characterize them in Neurospora tetrasperma

\begin{tabular}{|c|c|c|c|c|c|}
\hline \multirow[b]{2}{*}{$\begin{array}{c}\text { Con- } \\
\text { dition } \\
\text { of spores } \\
\end{array}$} & \multirow[b]{2}{*}{$\begin{array}{l}\text { Min. after } \\
\text { activation }\end{array}$} & \multicolumn{4}{|c|}{ Physiological marker: } \\
\hline & & $Q^{a} o_{2}$ & R.Q. ${ }^{\mathrm{a}}$ & $\begin{array}{l}\text { thermal }^{b} \\
\text { resistance }\end{array}$ & $\begin{array}{c}\text { deactivability } \\
\text { at } 4{ }^{\circ} \mathrm{C} \text {. }\end{array}$ \\
\hline Dormant & - & 0.5 & 0.6 & + & - \\
\hline \multicolumn{6}{|l|}{$\begin{array}{l}\text { Activated: } \\
\text { Stage \#: }\end{array}$} \\
\hline 1 & $0-20$ & $0.5-4$ & 1.2 & + & + \\
\hline 2 & $30-60$ & $4-10$ & 1.0 & - & + \\
\hline $3-\mathbf{n}$ & $60-150 \quad 15$ & $15-30$ & 1.0 & - & - \\
\hline Germinatin & ng 150 & 30 & 0.6 & - & - \\
\hline
\end{tabular}

(2) An inhibitor which maintains the cell in the dormant condition may be destroyed as a result of activation; deactivation would then be caused by the resynthesis of the inhibitor, prevention of its destruction or a combination of both. (3) Reactions involving more than one reactant at each step, or several steps which form a feedback system could also account for these observations.

At present, no decision between these alternatives is possible in the case of Neurospora ascospores. However, it seems likely that an important aspect of the change in the metabolism of these cells upon activation is the initiation of the use of trehalose (Lingappa, B. T., and Sussman, 1959: Sussman and Lingappa, 1959). Thus, lipids are the endogenous substrate of dormant spores whereas trehalose is utilized only after activation. How this change is initiated and how many steps are antecedent to it are still unknown.

Department of Biology

College of ST. Joseph

Albuquerque, New Mexico AND

DEPARTMENT OF BOTANY

UNIVERSITY OF MICHIGAN

Ann Arbor, Michigan

\section{LITERATURE CITED}

Emerson, Mary R. 1954. Some physiological characteristics of ascospore activation in Neurospora crassa. Plant Physiol. 29: 418-428.

GoDdArd, D. R. 1939. The reversible heat activation of respiration in Neurospora. Cold Spring Harbor Symp. Quant. Biol. 7: 362-376.

- AND P. E. Smith. 1938. Respiratory block in the dormant spores of Neurospora tetrasperma. Plant Physiol. 13: 241-264.

Halbsguth, W., and H. Rudolph. 1959. Untersuchungen über die Wärmeaktivierung der Sporangiosporen von Phycomyces blakesleeanus. I. Archiv Mikrobiol. 32: 296-308.

Holton, R. 1958. Pyruvate metabolism and electron transport in Neurospora. Dissertation. Univ. of Michigan. Ann Arbor.

Lingappa, B. T., and A. S. Sussman. 1959. Endogenous substrates of dormant, activated and germinating ascospores of Neurospora tetrasperma. Plant Physiol. 34: 466- 472 .

LingapPa, Y., And A. S. Sussman. 1959. Changes in the heat-resistance of ascospores of Neurospora upon activation and germination. Amer. Jour. Bot. 46: 671678.

Sussman, A. S. 1954a. Changes in the permeability of ascospores of Neurospora tetrasperma during germination. Jour. Gen. Physiol. 38: 59-77.

-1954b. The sensitization of ascospores to chemical activators by heat treatment. Mycologia 46: 143-150.

—_, J. R. Distuer, and J. Krakow. 1956. Metabolic aspects of Neurospora ascospore activation and germination. Plant Physiol. 31 : 126-135.

—, And B. T. Lingappa. 1959. Role of trehalose in ascospores of Neurospora tetrasperma. Science 130: 1343.

—_ , R. J. Lowry, and Elizabeth Tyrrell. 1959. Activation of Neurospora ascospores by organic solvents and furans. Mycologia 41: 237-247. 